Jarostaw Jendza

https://doi.org/10.26881/pwe.2020.49.11

ORCID: 0000-0001-7598-9085

Uniwersytet Gdański

jaroslaw.jendza@ug.edu.pl

\title{
Montessori as an alternative in post-totalitarian and 'folwark' educational culture - ethnographical research report
}

\begin{abstract}
Summary
The article addresses the issue of alternative education in the context of cultural codes. On the basis of ethnographic research conducted in primary Montessori schools in Poland the author analyses the significance of local culture for the global range pedagogy, and in this way questions the thesis according to which Montessori is indifferent to cultural differences. The results of the research show, that all three cultural codes, including the totalitarian and folwark ones are present in many different situations investigated during the research. At the same time Polish Montessori schools are undoubtedly these places in which the modernization code is overwhelmingly present.
\end{abstract}

Keywords: Montessori, ethnography, culture, cultural codes, alternative education

Słowa kluczowe: Montessori, etnografia, kultura, kody kulturowe, edukacja alternatywna

\section{Introduction}

Montessori pedagogy undoubtedly has a global range. It is practiced on all inhabited continents, in tens of countries, regardless their cultural diversity ${ }^{1}$. The number of educational institutions of this type is constantly increasing. From one side, Maria Montessori has becomea well-known logo or a commodified brand, but at the same time there are alsonumerous initiatives promoting this approach in various forms of public service for unprivileged communities or initiating public debate on children's rights ${ }^{2}$. This pedagogy is also an object of growing scientific interest (e.g. Marshall 2017; Denervaud et al. 2019)

\footnotetext{
See for example: https://montessori-europe.net/montessori-in-europe/montessori-europe-map/; https:// www.montessoricensus.org/schools-map; https://montessori.org.au/schools-and-centres-directory; http:// www.montessoriaroundtheworld.org/asia/; http://www.montessoriaroundtheworld.org/south-america/; http://www.montessoriaroundtheworld.org/africa/, 2.04.2020.

2 One of many initiatives like this is a network of Montessori practitioners Educateurs sans Frontières [Educators without Borders] supported by Association Montessori Internationale which main objective is to maintain and strengthen United Nations Development Goals, especially goal four that is connected with the right to equitable, inclusive and free education. More information can be found here: https:// montessori-esf.org/what-is-esf/educateurs-sans-frontières, 2.04.2020.
} 
and a topic of numerous publications addressed for non-expert audience, mostly parents (e.g. Eissler 2009; Seldin 2017).

These processes must provoke a hypothesis that Montessori pedagogy is currently becoming or simply is the most widely spread educational alternative. Nonetheless, it is also not questionable that there are some dimensions of this approach that might be interpreted differently in various educational cultures. Jerome Bruner coined the term of folk pedagogy and while showing its significance and relation with theory he observes that: "[I]n theorizing about the practice of education in the classroom [...] you had better take into account the folk theories that those engaged in teaching and learning already have. For any innovations that you, as a »proper « pedagogical theorist, may wish to introduce will have to compete with, replace, or otherwise modify the folk theories that already guide both teachers and pupils" (Bruner 1996: 46).

Bruner shows that some local and well domesticated patterns of understanding and dealing with various aspects of everyday life not only might, but simply do modify pedagogical theories. In his texts he does not however specify or verify empirically what he means when using the term modify, but it is clear that some translations occur when pedagogical theory faces folk pedagogies.

Nevertheless, the assumption that Montessori pedagogy can be identically understood and practiced all over the world is shared among many members of the community of "Montessorians" and, I must admit, a lot is done to keep this pedagogical approach as culturally indifferent as possible.

The main scope of this article is to explore deeper the aforementioned hypothesis formulated by Bruner. In other words, my main aim is to examine if, and possibly how, a local educational order (Hester, Francis 2000: 1-20) corresponds with the practices in Montessori educational institutions, and this article outlines the case of Poland. My starting point claim is therefore that although Montessori schools and kindergartens (or Case dei Bambini) might look exactly the same at first glance, they are in a way framed (Bateson 1972; Goffman 1974) by local cultures and thus, they are to some extent diverse.

The article is divided into four sections. First, I am going to characterise the two theoretical paths that can set the context for further analysis. Here the ideas of cultural codes (and culture as such) as well as possible dimensions of alternativeness will play a key role. Then, I outline the methodological foundations of ethnography and the subsequent steps of my research project. Finally, some of the results will be presented. In the conclusion part, I am going to end the article with the discussion of the whole argument.

\section{Cultural codes and the levels of educational alternativeness - theoretical frame}

The concept of cultural codes with the reference to Polish education has been developed by Piotr Zamojski, who understands them as"“...] particular, distinct systems of beliefs, assumptions, cognitive schemes and behaviour scripts, as well as institutionalised social arrangements, procedures and norms, that evolved thorough longue duréeprocesses to be- 
come intersubjectively shared and naturalised ways of being, acting, perceiving and thinking about reality" (Zamojski 2017: 417).

If follow his argument that any practice and perception is mediated and framed by a local culture, we need to accept that most probably the, so called, alternative forms of education are not the exceptions to the rule. In other words, even if some social practice originates in "distant" culture, while being implemented in a given locality, it is changed according to its frames. Up to this point it is as vague as Bruner's idea of cultural modification, but Zamojski goes further by the examination and reconstruction of the specificity of Polish educational imaginary and distinguishes three ideal cultural codes: the folwark, the totalitarian and the modernisation (Zamojski 2017: 419-428).

The first one (folwark) is connected with a few-hundred-year history of Poland and characterises possible relations between people who are either powerful landlords or slavelike pheasants. This hierarchy is built on the assumption that the inferior cannot think, is not reasonable, and therefore cannot be trusted, but rather is the object of contempt, and that the superior is egoistic, ruthless, unfair, and needs to be deceived in order the inferior to survive (Zamojski 2017: 419-420). Zamojski points out that "(...) the same person usually takes both possible positions (...) in different social constellations" (Zamojski 2017: 420). This "well-domesticated" (Bourdieu 1988: XII) frame of social interactions is not recognized, functions as something natural and precludes any other forms of mutual relations. From the perspective of Montessori theory this order or arrangement is something that has to be rejected. Maria Montessori pointed out many times that the humbleness of the adults and teachers as well as the unconditional respect and acceptance for the children's needs are the main foundations of her approach (see for instance: Montessori 1912, 2008). There is a lot of data showing clearly that in Polish mainstream educational reality teachers play the role of the almighty landlords who have the right to do whatever they find necessary to educate students (see for instance: Klus-Stańska 2002; Klus-Stańska, Nowicka 2005; Gawlicz 2009). Nonetheless, in Montessori education performing such practices would mean acting against the most fundamental values of this theory would mean contradicting the very essence of this pedagogical approach.

How do the teachers and other actors involved in Montessori education deal with this axio-normative "clinch"? We will come back to this question once the results of the research are presented and now let us turn to the second cultural code depicted by Zamojski.

Totalitarian code has shorter history and is connected with Stalin terror (up to 1956) and the Second World War influence. To make this claim Zamojski (2017: 422-423) follows Andrzej Leder (2014) and other researchers - underlines that it has resulted in one of the deepest changes in Polish mentality, the changes with which the society have been struggling up to now, regardless contemporary economic and political shifts. This code is characterised by the author in detail, but I would like to point to its one most characteristic feature, which is the tension between diversity or plurality versus unity (Zamojski 2017 : 423). Totalitarian logic seeks for unity and sameness (Zamojski 2017: 424). Therefore teachers, students, teacher training centres, and other social actors should perform their 
actions in a unified way. From that perspective, there should exists some central agency of power which defines what the desired unity (and therefore sameness) isand which imposes it on the margins. There is a unified model of an ideal school, there are shared and desired standards of all the procedures and actions taking place in educational institutions. Diversity, individual interpretations, unique realisations of educational processes are not welcome (cf. Klus-Stańska 2018: 63-93).

With the reference to Montessori, one might say that (for example) taking care of thestandards and/or assuring quality are aimed at maintaining true or genuine Montessori education thus avoiding ironically called "monte-something" institutions and practices. Therefore, some consensus - despite cultural diversity - must be reached (Bednarczuk, Zdybel (eds.) 2014), otherwise we would not be able to say whether a given institution is a Montessori one. That is true, however, the specificity as well as the goal of the totalitarian code in education is, as I pointed out above, to define "the desired One - an arché, in the sense of both principle and origin" (Bednarczuk, Zdybel (eds.) 2014: 423).

In other words, it can be assumed that seeking for the archetypic Montessori education might, on the verbalised surface, mean taking care of high quality education, presumably motivated by the desire to offer children optimal conditions of the development, but, on the subconscious, nonverbalised level, it can be the totalitarian code that may play an important role.

Obviously, these two mentioned underpinning principles do not exclude other possibilities, but, if we follow Leder's analysis (Leder 2014), the meaning of the totalitarian code in alldomains of life of Polish society cannot be ignored, ergo Montessori educational practices can be interpreted within this theoretical frame too.

The third cultural possibility analysed by Zamojski (2017) is called the modernization code. According to the author, it might be - in historical sense - associated with the workers' union known as Solidarność [Solidarity] which created a peculiar form of democratic procedures (Zamojski 2017: 426) and its structure is described as follows: "The central opposition structuring the modernisation code consists in a tension between reason and violence (...). Either we believe that all humans are rational beings, and therefore we can persuade each other in finding the best possible decision concerning all, or the strongest has to impose her/his particular rationality on all the others. Here, there is no centre of power. Nor are the masters and slaves. There are only diverse and equal interlocutors aiming at rationalisation of the social world (...). On the interactional level, the modernisation code means the seriousness of listening and speaking required in all social situations where interlocutors desire communal learning rather than violence" (Zamojski 2017: 426-427, emphasis added).

What seems to be significant in this cultural code, is probably the assumption that diversity and equality are the desired features of social life. We are all limited in our cognition, our perception of the world is partial and therefore we are, in a way, necessarily wrong. This means that we need to listen to the others, treat so called 'unquestionable authorities' with distance and develop critical thinking. Anything can and perhaps should 
become a subject of the detailed study or/and critique. It is therefore not a coincidence that Zamojski gives an example of the New Education Movement as one of possible manifestations of the modernization code in education (Zamojski 2017: 427).

Montessori undoubtedly is one of the key figures in this reformation initiative originating in XIX century. Following that path, we could form a hypothesis that a growing number of Montessori school and kindergartens is the sufficient empirical evidence that the modernization code has been becoming more and more powerful. We could also add that Polish educational landscape - especially with the reference to early education sector - is becoming more and more diverse, and thus we are more and more modern(ised).

Nevertheless, Zamojski points out that also this discourse has been being colonised by another paradigm - namely: neoliberalism (Zamojski 2017: 428-429). In other words, the modernization "path" is at stake and there seems to be no alternative (Zamojski 2017: 429). If so, Montessori practices in Polish context are also endangered in three different ways. Two threats are related to the first two cultural codes characterised above (folwark and totalitarian), and the third one is directly connected with the neoliberal shift (Mitchell 2006; Potulicka, Rutkowiak 2010).

The idea of cultural codes shows three ideal types in Weberian sense. It means that 1) all educational practices can be described within the logic and 2) each and every empirical type might be a mixture of the three codes. I claim that Montessori practices can be interpreted in that perspective especially in the country where the first two codes are so overwhelmingly present and persistent. I will come back to this claim later on, and now let me turn to what it means to investigate cultural dimension of education.

Research focused on culture is usually related to ethnography understood as "the study of groups and people as they go about their everyday lives" (Emerson et al. 2011:1) which means that the central category in this kind of research is the notion of culture (Geertz 1973; Clifford, Marcus (eds.) 1986; Atkinson 1990; Hammersley 1992).

Cultures and thus cultural codes can be researched in various ways depending on the understanding of what constitutes a given culture. In his conception of the cultural codes Zamojski refers to the notion of code (Zamojski 2017: 417), but for the empirical researcher it is necessary to think of some operational categories that could direct the research process (Neuman 2006). The answers to this dilemma are varied and numerous but once a researcher wishes to examine "the work" of cultural codes they have to operationalise these categories in order to focus "the lenses" of the field observation. Regarding my own inquiry I intended to follow two ideas.

Fons Trompenaars and Charles Hampden-Turner (1997) having conducted their research in business organizations, developed a sophisticated model of cultures' dimensions (Trompenaars, Hampden-Turner 1997: 21-23) showing that there is an outer, visible or explicit - as they call it, layer. Here we can find (inter alia) formally stated organizational documentation. With the reference to Montessori these are the explicitly formulated missions, visions and other written documents and/or openly uttered declarations. This is the layer in which Montessori theory might be located, provided it is not part of one's tacitor 
implicit knowledge (Polanyi 1966: 4). The middle layer is connected with the norms and values that function on both formal and informal level but they have different functions. "While the norms, consciously or subconsciously, give us a feeling of »this is how I normally should behave «, values give us a feeling of »this is how I aspire or desire to behave«. A value serves as a criterion to determine a choice from existing alternatives" (Polanyi 1966: 22). There is also an implicit layer where basic assumptions are found. As the authors say, it is primarily connected with the strive for survival (Polanyi 1966: 23), but they also formulate a piece of advice for the researches interested in this layer of cultural codes. As they say "The best way to test if something is a basic assumption is when the question provokes confusion or irritation. (...) When you question basic assumptions you are asking questions that have never been asked before. It might lead to deeper insights, but it might also provoke annoyance. Try in the USA or the Netherlands to raise the question of why people are equal, and you will see what we mean" (Polanyi 1966: 23). These basic assumptions are explicitly mentioned in Zamojski's theory of cultural codes, they are also present in Bruner's folk pedagogy (cf. Klus-Stańska 2018: 13-19). Trompenaars and Hampden-Turner suggest asking questions as the technique that may lead us to the discovery of this implicit layer but I am of the opinion that ethnographical observation of everyday practices can disclose it too. This claim becomes even more justified if we turn to the theory of the triad of culture by Edward T. Hall, which is a continuation and extension of the very well-known iceberg metaphor of culture (Hall 1990; cf. Kluckhohn, Strodtbeck 1961; Hall, Hall Reed 1989).

According to the triad conception, culture may be characterised by three different levels: technical, formal and informal or out-of-awarenessand in a way resembles Freudian concept of personality consisting of the conscious, subconscious and unconscious. Some translation theoreticians point out that the technical level can be linked with textbooks and manuals (Katan 1999: 31).

Following that path of interpretation, we can say that the aforementioned documents that are "on the surface". In the context of Montessori education these can be for example publications or albums ${ }^{3}$ that each and every Montessori teacher creates.

Formal level of culture is located "just under the surface" and mediates between the technical and the out-of-awareness level. It is connected with traditions, patterns of behaviour, customs and generally "accepted way of doing things" (Katan 1999: 31) and can be learnable - at least to some extent.

An example opposite to Montessori theory would be, if some would think that it is a good habit in (pre)school to follow teachers instructions on how to work with a given didactic material. Students learn that, either they work with this material in a proper way, or they are not ready to use it yet. An example that would be in line with Montessori approach, would be connected with the rule "to respect the freedom of choice in terms

\footnotetext{
3 Album is a personal document containing, inter alia, a set of procedures describing how to present and work with a particular material. All the teachers who have completed a certified Montessori course (teacher training programme) must have prepared such albums for various branches of knowledge.
} 
of cooperants" (Duffy, Duffy 2012). Children in Montessori kindergartens and schools quickly learn that the materials are for working (not playing) and they know that they cannot interfere in their peers' work unless invited.

The last level is called "out of our awareness" and it refers to a kind of mind-map that tells us how to do something. One might paraphrase Freud in this regard, and say that it is exactly this level of culture that is the "master of the house" (Freud [1917] 2001: 143). This lever of culture is not intentionally learned, it is rather acquired in the process of primary and secondary socialisation and thus it is naturalised, invisible - this is the air we breathe (Zamojski 2017: 418).

The two aforementioned theoretical stances related to the possibilities and limitations of researching culture(s) provoke another question. If we can distinguish layers or levels of culture(s), we need to problematise the notion of alternativeness that is mentioned by Zamojski with the reference to the modernisation code. My point here is that Montessori, as an exemplification of alternative pedagogy, can be investigated on different levels and it may turn out that certain layers of this pedagogy are not so alternative or modernised as we sometimes tend to think.

On the other hand, the concept of cultural codes might be a useful "orientation" and explanatory tool to research this educational approach in relation to Polish specificity.

Obviously, the theoretical frame presented at this point of argument was generated a posteriori, after having analysed the empirical material, but before I briefly outline the methodological approach and procedure, let me offer a synthesis of what has been established so far.

My vision of the empirical exploration of Montessori education is culturally sensitive and fits in well with a matrix in which the horizontal order is defined by the cultural codes and by the vertical one that refers to the layers or levels of culture. In this way I make an initial attempt to explore "the translations of educational cultures" which may become one of the central questions in comparative research in the future.

\section{Method}

In research methodology there is usually a shared consensus in defining particular methods, strategies or approaches. Ethnography, however, is understood in many different ways since it has been numerously recontextualised and its history is connected with plenty of (sometimes opposite) social research paradigms (Hammersley, Atkinson 2007: 2). That is probably why it is, at times, described in a practical way by outlining what ethnographers actually do (Hammersley, Atkinson 2007: 3).

It can be said that most often the researcher takes part in everyday life of the group she/he is interested in (Prus 1996; Shaffir et al. (eds.) 1980). That means that at least some data gathered in this kind of research is not initiated by the researcher, as it is the case in surveys, or structured interviewing. Of course, it does not mean that interviewing is prohibited here, but usually it is the observation that plays the most significant role. In 
this sense, ethnography, especially at the initial stage of the research process is an openended approach (Maxwell 2004). At the beginning of the process researchers usually do not know what aspect of the analysed group will turn out to be the scope of investigation, and the main research question is usually clarified throughout the examination rather than a priori predefined (Erickson 1977: 62-64; Wolcott 1999: 67-71; Roper, Shapira 2000).

Having said that I would not like to imply that in ethnography anything goes. There are attempts in literature to list a set of criteria specifying what constitutes a "well-done" ethnography research project (Atkinson, Hammersley 1994; Atkinson et al. 1999; Prus 2005: 20-23; Monorouxe, Ajjawi 2020). I find some of these suggestions particularly important, and I followed them while conducting my research. The first two requirements are connected with being attentive to the activities of those whose lives a researcher is studying.

Sometimes while reading research reports I have a feeling that the authors do not really try to understand the Other but rather domesticate the exotic (Bourdieu 1988) by positioning the examined groups as the less aware, educated or civilised (Said 1978, 1994; Rosaldo 1993).

In this ethnographic inquiry, following Janusz Korczak's idea of humble observation, I have been trying as much as possible to listen, comprehend and appreciate (Korczak 1924) rather than to illustrate my own point with some extracts of the empirical material gathered throughout the research process (Wolcott 1999).

In my ethnography I do not pretend that I am neutral. I have been supporting Montessori educators for years and I do think that, to a large extent, this idea of education has the potential to create much more optimal conditions for holistic development than any other form of traditional schooling (cf. Cossentino 2005). At the same time, I have been trying to keep "the critical eye" open because that is, in my opinion, the vocation of any educational researcher (Bittner 1988: 155). Ethnographer should, from one side, be familiar with this methodological approach but also need to be aware that s/he is ignorant (Fetterman 1998; cf. Rancière 1991).

My idea of the research is referred to as focused ethnography (Erickson 1977; Hammersley 1992; Andreassen et al. 2020: 297), which means that it is related to specific episodes and interactions (Roper, Shapira 2000; Andreassen et al 2020: 300) and does not claim the right to describe full image of the cultures researched (Wall 2015).

The research was conducted in two Polish Montessori primary schools where I studied the children's communities in the first three years of the second plane of development (Grazzini 2004: 35), so the kids at the age 6-9 (Montessori 1948, 1949, 1971: 4-10, 1973). Throughout the period between 2014 and 2020 I observed four different groups of children between 14 and 28 members each, mainly during the free work cycle time but occasionally also in different situations (in the garden, on excursions, during meals and school festivals). In total the observation includes 96 hours of free work periods and 11 hours in other situations. As I mentioned before, the main occasion for gathering data was non-participant observation, but I also collected empirical material with the use of participant observation, twelve non-formal conversations with teachers lasting from 3 to 15 min- 
utes, one in-depth interview (90 minutes) and regular (weekly) study of the organizational documents in the form of the children's notebooks and daily planners.

The empirical material consists of four types of written record. The first one is jottings (Emerson et al. 2011: 29), which are "brief written records of events and impressions captured in key words and phrases" (Emerson et al. 2011: 29). The second one is commentaries including reflections taken down after the observation. They were usually first recorded in a form of voice-notes and later transcribed, edited, re-overthought and usually re-edited. The third, and the dominant form, the fieldnotes, were taken at the moment of non-participant observations. They are usually lengthy written day-entries including "clinical" observations of the events and interactions in the classrooms (Emerson et al. 2011: 75). The last type of the empirical material is a word-to-word transcript of the indepth biographical interview with one of the teachers.

It is important to remember that in my ethnography making different type of notes was not simply a way, method or technique to gather the "raw" material. I claim that writing can be understood as a form of studying. In other words, through writing one can study a given subject matter (Eddy 2016). In this perspective note making (not 'taking'!) is something that Jan Masschelein and Maarten Simons refer to as a pedagogical form. Following this idea, Joris Vlieghe and Piotr Zamojski show the peculiarity of note making taking place in, around and after academic lecturing (Vlieghe, Zamojski 2020). I believe that research-making-notes is, in this sense, not much different. The authors say that " (...) the student, once the lecture is over, can reconstruct - on the basis of her notes - the narrative structure of the whole lecture. This is, based on these notes, the student e.g., in the privacy of her own study room, can now teach to herself. She can re-enact the lecture, so to speak, and step by step recreate the story which the lecturer has brought" (Vlieghe, Zamojski 2020: 7).

The researcher observes and listens to the world of children in their (?) environment. She/he studies the field. Naturally, there is no teacher who had prepared her notes so there is no previous note making (Vlieghe, Zamojski 2020:7) but surely there is a narrative of the field that is studied through listening-observing-note-making process. My claim is, therefore, that (re)writing is an archetypical form of academic study not only in the situation of lecturing but also while investigating a research matter (Emerson et al. 2011: 86).

Having made all the notes, I started coding the material. Since the purpose of whole research project is multi-cultural comparative analysis, open coding has been used. However, in this article I present only a small part of (two institutions in one country) and therefore focused coding seems to be more justified (Emerson et al. 2011: 172). The focus is on the 'work' of cultural codes and the layers in Montessori primary school environment.

The next usual part of most research reports is "the results". In the case of the text presented, I have decided to present a few 'snapshots' of the research material first and then offer one of many possible ways of interpreting the material. The extracts shown below are not random. My aim, at this stage, is to offer the reader 'the flavour' of the complexity as well as the 'flickering' of cultural codes and culture layers. 


\section{Snapshots}

\section{Sue and Tom}

Sue (9) and Tom (7) are sitting on in front of the white rug. 9:15. Kindergarten material on the floor. Why 3-6 material is here? How come? Sue is comfortable. The palm of her left hand is relaxing on the knee. Tom, intrigued, in half-sit-down, focused on the wooden shapes. Why kindergarten here? Rectangle, circle and triangle are out. Sue starts the lesson. Sue: Please bring the rectangle.

Tom stands up without a word and silently goes away.

Tom: I have it.

Sue: Put it here. Her index finger shows the right place, right above the rug. Now please go for a circle.

Tom stands up without a word, silently goes away and brings the circle after 10 seconds.

Sue: (taking the circle) Can I see it? Tom doesn't say a word and gives it obediently to Sue. Sue: (pointing with her righthand index finger) What is it Tom?

Tom: Rectangle.

Sue: (nodding her head) Rectangle. And this?

Tom: Triangle. Sue nods her head.

Sue: And this?

Tom: Circle.

Sue: Now take the circle to Mr Chris. Tom goes and quickly comes back. Tom wants to stand but Sue takes him by the hand and asks him to sit next to her. The lesson is not finished. Now take the triangle and put it on the window. Tom goes and doesn't come back. The lesson is finished. Sue is puzzled. Looks around. Tom is nowhere to be seen. She takes the material and goes out of the classroom. Is she going to the kindergarten? Have I just seen 3-6 album alive?

\section{Déjà vu}

I am a promotor of BA thesis Spontaneous peer tutoring in Montessori pre-schools. The student sends a film. The same picture. Another girl teaching another boy. Position of the bodies. Language of instruction. Movement, behaviour, gestures. Only the setting slightly different. Have I seen the living album again?

\section{Therapy}

Andrew (9) wants to write a postcard like the other children. Andrew is not like other children. Andrew has got personal shadow therapist.

Andrew: I want to work with Tina.

Therapist: You know what we have to do. She takes him by the shoulder and points to the table in the corner. The corner is distant. In the corner you can focus, she says. Can you? Therapist: (very slowly, stressing some sounds) Noowweeearee going to fiiiniiish your writing. Taake out your planeeeer.

Andrew doesn't want so she pushes him onto the chair. Does she need so directive and behavioural treatment? Who is Andrew? What are his deficiencies. Deficiencies? Later we talk about it. 
Therapist: He is from a difficult family. His dad, well his dad officially doesn't work. But where does all their money come from? His mum works, we know that for sure. Once he put scissors in other kid's ear! We are afraid to take him for the excursion to the forest.

In the meantime, Andrew slipped out of the chair and now is lying under the table, writing when nobody is watching. Suddenly he stands up and goes to the whiteboard. He is rewriting his "secret piece": Dad - I wish you much.

He stops after each word. The therapist is tired and indifferent. Andrew goes away, comes back and continues writing. After a minute:

Andrew: Miss, I want to go out, to the garden.

The therapistdoes not respond, so he goes to a leading teacher, Sara.

Andrew: What can I wish to my dad?

Sara: (looking at his piece of writing) Don't forget about proper greeting forms and opening phrases like: "Dear".

\section{Rooster}

Jim: Miss Alex, how shall I make this paper rooster?

Alex: What characterises each and every rooster?

Jim: (confused) I don't understand.

Alex: (impatiently) What does each rooster have?

Jim: Red tail?

Alex: Each rooster has a tail that is coloooo... (rising intonation)

Jim: Colourful!

Alex: So, you have to paint a colourful tail.

\section{Free work}

I enter the class at 10.31. The free work period is well in progress. Three students are wearing protective headphones in order to have peace and quiet. They seem to be at the leisurely stroll, wandering around aimlessly and happily. Raymond is working on the letter to his grandma. It reads: Dear Grandma, I wish you a lot of love for your grandchildren. Yours, Raymond. I ammoved, almostcrying. Jasmine reads out her letter to three other kids sitting at the dining table. She is surely proud of what she had done. Raymond has nothing to do so he interrupts the others. One of them says: Not now please, I'm working. Raymond goes to the window. 10.57. He is given a Halloween word-search and jumps into it eagerly. $11.00-$ Pupils remind one of teachers about the end of the first (out of two) cycle of free work. The teacher turns on CD player. It is subtle but audible.

Circle/Ellipse time. All the children gather in a circle. Anyone would like to tell us what you have been working on? Seven hands up. Ann, tell us.

Ann: I've been finishing my presentation on Australia.

Teacher: Would you like to tell us something about your presentation?

Ann: Not yet. I must finish it first.

Teacher: Are you happy with your work during the last three hours?

Ann: Yes and no.

Teacher: Why yes? Why no? 
Ann: I drew a map of Australia. It is brown and nice, but I still have a lot to do.

Teacher: $O K$, so what's your plan?

Ann: I'll try to finish it by Wednesday.

Teacher. OK, thank you Ann, anybody else?

\section{The lesson was nice. Was it?}

Monday, 9.20. Samantha-the most experienced teacher in this school is conducting a lesson for 5 girls. It is about the months of the year. She is sitting on the floor with the kids around looking at her carefully.

Samantha: (showing a calendar) What is it?

Pam: Calendar.

Samantha: Yes, calendar. What is it for?

Jo: To know the day.

Pam: To remember one's birthday! (almost shouts and bursts out laughing)

Samantha: Look these cards have the names of the months. Would you put them in chronological order?

All kids: Yes! Students are putting the months on the floor reading aloud at the same time. One after another, one after another. The teacher is silent, physically close but invisible until all the kids have finished reading.

Samantha: Do you know that we have various calendars? (without waiting for the answer) For example, this is a wall calendar, and this is perpetual calendar, and here I have a seasonal calendar. Do you think you can design a round calendar on this paper plates?

All kids: Yes! They jump up happily. The teacher distributes the plates. 9.34.

Pam: Can we do it together?

Samantha: But what would you like to do?

Pam: I don't know, but you will tell us what to do.

Sue to Pam: Maybe you're going to do what you will think of...

Two other kids come. Can we join?

Samantha: Yes, of course. (9.44)

Pam: Can we do it in pairs?

Samantha: Yes.

Liz: Can we use the internet to inspire?

Samantha: Yes. But look, here I have one inspiration, also downloaded from the internet. The teacher shows a printed version of round, paper calendar. Pupils go away and start working. I go around and observe them work. After 30 minutes 4 calendars are ready.

Pam, Liz and Jo: Miss, miss look! We have done our calendars!!! Are they nice?

Samantha: Show me, please. Can you tell me something about your calendar? Girls describe their work.

Pam: The lesson was nice, thank you.

Samantha: I thank you. 10.15.

All the calendars are "copies" of the inspirations from the internet presented by the teacher. Was the lesson nice? I come back home with this question in my head. 


\section{Recruitment meeting or a Mad Tea-Party (auto-ethnographical observation note)}

We are all stressed. Everybody is elegant. We are waiting nervously. Will anybody come? This is the day. We are recruiting families for the school. Tea and cookies are waiting too. I need to start the meeting and talk about Montessori pedagogy to our possible families and also maybe clients. My presentation is ready. Are you a distancing academic or are you marketing specialist? Can you be both? Who am I now? Here is one couple. We're not going to be alone. Aah.

OK, we canstart?

P1: Yes, probably nobody else is going to come. There are 12 of us -7 people of the staff and 5 parents. Not many.

P2: Ok, generally I agree with this vision of childhood and education, but how are you going to test their knowledge?

S: We don't test.

P2: Nonsense! So, how do you know if they learn?

S: There are other forms of getting to know what the kids know, more student-and-development friendly. (...)

P1: Fine, but how are you going to give them marks?

S: We don't give marks.

P1: Never? At all?

$\mathrm{S}$ : Nope, we use descriptions of progress in various areas.

P1: Ridiculous! In real world people are being assessed all the time.

P4: How about some homework, they need to revise, right?

$\mathrm{S}$ : In our school there is no homework. We work here and at home kids should relax, develop their interests, hobbies and meet friends.

P4: This is not going to work. Sorry.

Do I have some pervert pleasure in being the Cheshire Cat? No, I don't.

\section{Interpretation \& Concluding remarks}

One of the claims formulated earlier in this text was that the analysis of the dynamics of culture layers and cultural codes may shed some light on the complexity of contexts in which Montessori pedagogy, as an example of alternative approach, is intertwined.

First of all, it must be said that in one educational situation various codes (sometimes three of them) can be identified in different layers.

For example, if we took a closer look at the situation when Sue was giving a spontaneous lesson to Tom, the modernization code is present in all three layers. However, it is also clear that Sue followed a certain pattern of doing the lesson, the pattern that is highly unified and probably treated as the right one. The relation between the girl and the boy can also be described by all the codes. From one side, nobody had told them to take part in the lesson, they are free people making sovereign choices and managing the situation in their own way and the school organization makes it possible for such peer tutoring to happen. Nonetheless, once mutually accepting the three-step lesson, Tom immediately plays the 
role of an obedient child and Sue becomes a very instructive, well-trained conservative teacher. She even uses gentle form of physical violence by making him sit next to her towards the end of the lesson when it is necessary to finish the lesson.

Similar relation is present between Andrew and his therapist. Her manner of speaking, subtle forms of physical pressure. She openly formulates rationalizations for such behaviours. These are Andrew's deficiencies as well mistakes of his parents that force her to treat him in this way. Of course, we know this tune too well. On the other hand, when he starts writing neither the teachers nor the therapist intervene. He has the right to do it as long as he does... what is included in the nonverbalized "catalogue of proper school activities".

Sometimes the situations are fairly clear. Rooster painting is one of them. Here, it is the teacher who says what has to be done and specifies in exactly what way. Rooster is being unified, one version is allowed. The modalities of the teacher's sentences, the grammatical and semantic aspect of her words are characteristic for folwark code so overwhelmingly present in Polish mainstream educational system. No alternativeness is to be found in this situation. Nevertheless, such situations are very rare.

Montessori schools in which the research was conducted are undoubtedly offer alternative education, education that is characterized mainly by the modernization code, especially on the first two levels. At the same time, this alternativeness is constantly "attacked", on the out-of-awareness level. Montessori teachers do create educational spaces that resist totalitarian and folwark reality (see: Free work, The lesson was nice. Was it?, Recruitment meeting or a Mad Tea-Party), but in Polish context this resistance is very difficult. That is why much more emphasis should be put on teachers' emancipatory competences rather than technical skills.

\section{References}

Andreassen P., Christensen M.K., Møller J.E. (2020), Focused ethnography as an approach in medical education research. "Medical Education", 54.

Atkinson P. (1990), The Ethnographic Imagination: Textual Constructions of Reality. New York, Routledge.

Atkinson P., Coffey A., Delamont S. (1999), Ethnography: Post, past, and present. "Journal of Contemporary Ethnography", 28(5).

Atkinson P., Hammersley M. (1994), Ethnography and participant observation. In: N.K. Denzin, Y.S. Lincoln (eds.), Handbook of Qualitative Research. Thousand Oaks, CA, Sage.

Bateson G. (1972), Steps to an Ecology of Mind: Collected Essays in Anthropology, Psychiatry, Evolution and Epistemology. San Francisco, CA, Chandler.

Bednarczuk B., Zdybel D. (eds.) (2014), Learning in the Montessori Classroom - In Search of Quality in Education. Lublin, Wydawnictwo UMCS.

Bittner E. (1988), Realism in Field Research. In: R.M. Emerson (ed.), Contemporary Field Research: A Collection of Readings. Prospect Heights, IL, Waveland.

Bourdieu P. (1988), Homo Academicus. Stanford, CA, Stanford University Press. 
Bruner J.S. (1996), The Culture of Education. Cambridge MA, London, Harvard University Press

Clifford J., Marcus G.E. (eds.) (1986), Writing Culture: The Poetics and Politics of Ethnography. Berkeley, University of California Press.

Cossentino J. (2005), Ritualizing Expertise: A Non-Montessorian View of the Montessori Method. “American Journal of Education", 111.

Denervaud S., Knebel J-F., Hagmann P., Gentaz E. (2019), Beyond executive functions, creativity skills benefit academic outcomes: Insights from Montessori education. "PLoS ONE" 14(11): e0225319, https://doi.org/10.1371/journal.pone.0225319, 2.04.2020.

Duffy M., Duffy N. (2012), Love of Learning. Supporting Intrinsic Motivation in Montessori Students. Santa Rosa, CA, Parent Child Press - A Division of Montessori Services.

Eddy M.D. (2016), The interactive notebook: How students learned to keep notes during the Scottish Enlightenment. "Book History”, 19(1).

Emerson R.M., Fretz R.I., Shaw L.L. (2011), Writing ethnographic fieldnotes. Chicago \& London, The University of Chicago Press.

Eissler T. (2009), Montessori Madness! A Parent to Parent Argument for Montessori Education. Georgetown, TX, Sevenoff, LLC.

Erickson F. (1977), Some Approaches to Inquiry in School-Community Ethnography "Anthropology \& Education Quarterly", 8(2).

Fetterman D.M. (1998), Ethnography step by step. Thousand Oaks, CA, Sage.

Freud S. (2001), A Difficulty in the Path of Psycho-analysis. In: The Standard Edition of the Complete Works of Sigmund Freud. Vol. 17. London, Vintage.

Gawlicz K. (2009), Preschools Play with Power: Constructing the Child, the Teacher and the Preschool in Two Polish Childcare Institutions. Roskilde, Roskilde Universitet.

Geertz C. (1973), The Interpretation of Cultures. New York, Basic Books.

Goffman E. (1974), Frame analysis: An essay on the organization of experience. London, Harper and Row.

Grazzini C. (2004), The Four Planes of Development. "NAMTA Journal", 29(1).

Hall E.T. (1990), The Silent Language. New York, Doubleday.

Hall E.T., Hall Reed M. (1989), Understanding Cultural Differences. Yarmouth, Maine, Intercultural Press.

Hammersley M. (1992), What's Wrong with Ethnography? London, Routledge.

Hammersley M., Atkinson P. (2007), Ethnography. Principles in Practice. 3rd ed. London-New York, Routledge.

Hester S., Francis D. (2000), Ethnomethodology and Local Educational Order. In: Hester S., Francis D. (eds.), Local Educational Order: Ethnomethodological Studies of Knowledge in Action. Amsterdam, PA, John Benjamins Publishing Company.

Katan D. (1999), Translating Cultures. An introduction for Translators, Interpreters and Mediators. Manchester, St. Jerome Publishing.

Kluckhohn F., Strodtbeck F.L. (1961), Variations in Value Orientations. Evanston, IL, Row, Petersen.

Klus-Stańska D. (2002), Konstruowanie wiedzy w szkole. Olsztyn, Wydawnictwo Uniwersytetu Warmińsko-Mazurskiego w Olsztynie.

Klus-Stańska D. (2018), Paradygmaty dydaktyki. Myśleć teoria o praktyce. Warszawa, Wydawnictwo Naukowe PWN.

Klus-Stańska D., Nowicka M. (2005), Sensy i bezsensy edukacji wczesnoszkolnej. Warszawa, WSiP. 
Korczak J. (1924), Momenty wychowawcze. Nasza Księgarnia, Warszawa-Łódź.

Leder A. (2014), Prześniona rewolucja. Ćwiczenie z logiki historycznej. Warszawa, WydawnictwoKrytykiPolitycznej.

Marshall Ch. (2017), Montessori education: a review of the evidence base. "Science ofLearning", 2(1).

Masschelein J., SimonsM. (2013), In Defence of the School: A Public Issue. Leuven, Education, Culture \& Society Publishing.

Maxwell J.A. (2004), Qualitative Research Design: An Interactive Approach. Thousand Oaks, CA, Sage.

Mitchell K. (2006), Neoliberal Governmentality in the European Union: Education, Training, and Technologies of Citizenship. "Environment and Planning D: Society and Space", 24(3).

Monorouxe L., Ajjawi R. (2020), Ethnography, methodology: Striving for clarity. "Medical Education", 54(4).

Montessori M. (1912), The Montessori Method. New York, Frederick A. Strokes Company.

Montessori M. (1948), To Educate the Human Potential. Aydar, Madras, Kalakshetra Publications.

Montessori M. (1949), The Absorbent Mind. Adyar, Madras, The Theosophical Publishing House.

Montessori M. (1971), The Four Planes of Education. In: M.M. Montessori (ed.), Lectures given in Edinburgh, 1938, and London, 1939. "AMI Communications", 4.

Montessori M. (1973), From Childhood to Adolescence. New York, Schocken.

Montessori M. (2008), The Child, Society and The World: Unpublished Speeches and Writings. Amsterdam, Montessori-Pierson Publishing Company.

Neuman W.L. (2006), Social Research Methods. Qualitative and Quantitative Approaches. New York, Pearson.

Polanyi M. (1966), The Tacit Dimension. University of Chicago Press, Chicago.

Potulicka E., Rutkowiak J. (2010), Neoliberalne uwiktania edukacji. Kraków, Impuls.

Prus R. (1996), Symbolic Interactionism and Ethnographic Research: Intersubjectivity and the Study of Human Life Experience. Albany, NY, University of New York Press.

Prus R. (2005), Studying Human Knowing and Acting: The Interactionist Quest for Authenticity. In: D. Pawluch, W. Shaffir, Ch. Miall (eds.), Doing Ethnography. Studying Everyday Life. Toronto, Canadian Scholars' Press.

Rancière J. (1991), The Ignorant Schoolmaster. Five Lessons in Intellectual Emancipation. Stanford University Press, Stanford.

Roper J.M., Shapira J. (2000), Ethnography in Nursing Research. Thousand Oaks, CA, Sage.

Rosaldo R. (1993), Culture \& Truth. The Remaking of Social Analysis. Boston, Beacon Press

Said E.W. (1978), Orientalism. New York, Pantheon Books.

Said E.W. (1994), Culture and Imperialism. New York, Vintage Books.

Seldin T. (2017), How to Raise an Amazing Child the Montessori Way. 2nd ed. London, DK.

Shaffir W.B., Stebbins R.A., Turowetz A. (eds.) (1980), Fieldwork Experience: Qualitative Approaches to Social Research. New York, St. Martin's Press.

Trompenaars F., Hampden-Turner Ch. (1997), Riding The Waves of Culture: Understanding Diversity in Global Business. London, Nicholas Brealey Publishing.

Vlieghe J., Zamojski P. (2020), Entering the world with notes: Reclaiming the practices of lecturing and note making. "Educational Philosophy and Theory", https://doi.org/10.1080/0031857.202 0.1743271 
Wall S. (2005), Focused Ethnography: A Methodological Adaptation for Social Research in Emerging Contexts. "Forum: Qualitative Social Research", 16(1).

Wolcott H.F. (1999), Ethnography: A way of seeing. Walnut Creek, CA, AltaMira Press.

Woods P. (2005/1986), Inside Schools. Ethnography in educational research. London-New York, Routledge.

Zamojski P. (2017), Cultural codes and education in Poland - a plea for a new educational imaginary. "Policy Futures in Education", 16(4). 